\title{
Spatial variation of in-migration to Moscow: Testing the effect of housing market
}

This is the final peer-reviewed version of the manuscript.

The paper was accepted for publication in $\underline{\text { Cities }}$ on 30 May 2016

DOI: $10.1016 /$ j.cities.2016.05.025

\section{Ilya KASHNITSKY $^{\text {a, b, * }}$, Maria GUNKO ${ }^{\text {c }}$}

${ }^{a}$ National Research University Higher School of Economics, Myasnitskaya 20, 101000 Moscow, Russia

${ }^{\mathrm{b}}$ Netherlands Interdisciplinary Demographic Institute / University of Groningen, Lange Houtstraat 19, 2511CV The Hague, The Netherlands

c Institute of Geography, Russian Academy of Sciences, Staromonetniy pereulok 29, 119017 Moscow, Russia

* Corresponding author: Tel. + 31 (0)70 3565214.

E-mail addresses: ikashnitsky@hse.ru, kashnitsky@nidi.nl, ilya.kashnitsky@gmail.com 


\section{ABSTRACT}

The collapse of state socialism and the introduction of market relationships in Central and Eastern Europe resulted in profound changes of urban development. Evidence from Central and Eastern Europe indicates that the development of a strong housing market and growing material inequalities contribute to the socio-economic polarization of city districts and residential segregation. Based on empirical data, we analyze spatial variation of migrants' first residential choices within Moscow, i.e. intensity of in-migration to a specific district. We test the theory-driven hypotheses about the association between residential choices and housing prices. Our results show that there are some areas that attract migrants of specific socio-economic status. However, housing prices do not explain a substantial share of variance in the intensities of in-migration, at least at the level of city districts; quite a strong association is only evident for foreign migrants. Thus, we find limited evidence of the Moscow' socio-spatial structure polarization due to the residential choices of migrants.

\section{KEYWORDS}

Post-socialist urban development, Moscow, Migration, Residential choices, Housing market

\section{HIGHLIGHTS}

- Internal migration accounts for more than $90 \%$ of in-migration to Moscow

- Internal migrants' residential patterns are more heterogeneous than immigrants'

- Immigrants from neighboring countries mostly settle in peripheral districts

- Immigrants from remote countries settle in prestigious central districts

- Housing prices explain a limited variation of migrants' residential choices 


\section{INTRODUCTION}

More than two decades have passed since the collapse of the state socialism across countries of Central and Eastern Europe (CEE). The exposure to global market and neoliberal economic policies have had a noticeable impact on their urban and regional development, as well as the life of the society (Marcińczak, Gentile, \& Stępniak, 2013; Round \& Williams, 2010). Neoliberal shift in economy increased inequalities in development, which have a pronounced spatial pattern. In other words, spatial development of the post-socialist countries is becoming increasingly polarized (Ehrlich, Kriszan, \& Lang, 2012; Fischer-Tahir \& Naumann, 2013). A characteristic feature of the polarized development is the intensification of migration flows from economically weak to economically prosperous areas (Weck \& Beißwenger, 2014). The majority of the latter are capital cities and areas in their proximity that experience fast population growth (Ehrlich et al., 2012; Kashnitsky \& Mkrtchyan, 2014).

Since the 1990s, the intensive in-migration to the post-socialist capitals along with the increased residential mobility within the cities have largely contributed to the substantial transformation of their residential areas, altering appearance and social structure (Haase, Grossmann, \& Steinführer, 2012; Hess, Tammaru, \& Leetmaa, 2012; Kährik, Leetmaa, \& Tammaru, 2012; Kubeš, 2013). If under state socialism housing was distributed on the priority basis according to the decision of the authorities (Gentile \& Sjöberg, 2006; Hess et al., 2012; Vendina, 2002), under market conditions the residential choices of households depend on individual needs/aspirations and are limited by the available resources (Mulder \& Wagner, 1998). Previous research suggests that people of the same race, ethnic origin, and social status tend to choose housing in the neighborhoods where people alike live (Musterd, Marcińczak, Van Ham, \& Tammaru, 2015; Quillian, 2002; Schelling, 1972; Van Ham \& Tammaru, 2016). Since residential choices are limited by the available to the household resources, then they to some degree associate with housing prices. Brasington, Hite, \& Jauregui (2015) and Musterd et al. (2015) find evidence that low and high income households concentrate in different parts of the city. The inflow of migrants of different social status, ethnic origin and various income levels reinforces the preset differentiation of neighborhoods and districts as a result of the first residential choices (Bolt \& Van Kempen, 2010).

The present study focuses on migrants' first residential choices within a post-socialist capital city. We investigate the spatial patterns of in-migration flows to city districts and test the association with housing prices. Such an association would be an evident sign of the polarization of city's sociospatial structure. Our study builds upon previous research on post-socialist capitals and major cities the ongoing residential changes and mobility within them (Haase et al., 2012; Hess et al., 2012; 
Kährik et al., 2012, 2012), polarization and segregation (Marcińczak, 2012; Sýkora, 2009; Vendina, 2002).

The empirical evidence is drawn from Moscow, the largest and one of the most migration attractive capital cities of the post-socialist / post-soviet space (Makhrova, Nefedova, \& Treivish, 2013). With a notable stability Moscow has been gaining roughly one million people each decade in the 20-th century (Denissenko \& Stepanova, 2013) despite the social shocks ${ }^{1}$ and persistent struggle of authorities to inhibit the process (Hausladen, 1985). In the post-soviet period the removal of administrative barriers restricting migration to the large cities as well as the economic stagnation, low wages, unemployment, and poor amenities in many Russian regions contributed to the intensification of migration to Moscow (Andrienko \& Guriev, 2004). Besides economic stimulus, common motives for migration to Moscow include education and family reasons (Kashnitsky, Mkrtchyan, \& Leshukov, 2016). According to the survey conducted by the Russian center for public opinion research, one fifth of Russians (19\%) would like their children to live in Moscow (Zayonchkovskaya \& Mkrtchyan, 2009). Thus, Moscow is an illuminating case study site for investigating migrants' first residential choices in the post-socialist capitals.

In order to answer our research questions, we analyze the types of migration flows in terms of sex, age, place of origin, and their intensities for 125 districts of Moscow, exploring variation by housing prices. The intensity of in-migration to Moscow's districts is in fact the amount of people who registered within a district for a period over 9 months - rented or bought housing; thus, its spatial variation provides information on migrants' first residential choices within the city. Until now, such research for Moscow was not possible due to the scarcity of data on migration. However, quite recently a detailed data set on migration flows for 2012 at the city district level was published (Federal State Statistics Service, 2012). Although the quality of data should not be overestimated, there is a hope that they are capturing the real process a bit better than they used to do previously (Kashnitsky \& Mkrtchyan, 2014; Zayonchkovskaya \& Mkrtchyan, 2009). A serious limitation of the dataset is that it is published for 1 year only; however, we believe that it would still allow to identify the main features of the phenomenon under study. All in all, the present research on Moscow at the level of city districts allows us to add up on the knowledge of urban development and population mobility in the post-socialist and especially post-soviet context, which is still underrepresented in the international academic literature.

\footnotetext{
${ }^{1}$ Moscow population reduced from $2.04 \mathrm{mln}$ to $1.03 \mathrm{mln}$ during the Revolution and Civil war of 1917-1920. Similar outcomes happened during the Second World war when Moscow population dropped from $4.2 \mathrm{mln}$ in 1940 to $2.0 \mathrm{mln}$ in 1942 (Vendina, 2012).
} 


\section{POST-SOCIALIST SOCIO-SPATIAL CITY STRUCTURE AND POPULATION MOBILITY}

The socio-spatial structure of cities under socialism was argued to be less polarized and segregated than in a typical capitalist city of the same time period (D. M. Smith, 1996; Szelenyi, 1987; Weclawowicz, 2002). Socialist cities were developing under central planned economic model. The absence of an open market - i.e. state-control over housing, goods and services - insured their distribution to different population groups, as was mentioned above, on the priority basis (Borén \& Gentile, 2007). Inequality in the access to housing existed, albeit, of different nature; social status was the indicator of being privileged in the society (Vendina, 1997). The privileged social strata consisted mainly of party nomenclature, military, scientists, as well as individuals who represented the country on the international arena (e.g. sportsmen, musicians, artists, diplomats). Thus, despite the income equalization, the above mentioned social groups had an access to better housing (Szelenyi, 1978).

According to Sýkora (1999), the creation of the socio-spatial differentiation within socialist cities was driven by two main factors. The first one is that the inner structure of those cities, that were not founded under socialism, was composed of districts build up in different era - pre-socialist and socialist. The high quality pre-socialist quarters usually housed people of higher social status measured in terms of occupation and education (Marcińczak, 2012; Sýkora, 1999). The second factor is associated with newly built housing estates. The priority-based differentiation of economic activities had also an impact on residential patterns; people of different occupations got housing in certain newly built areas of the city. Naturally, those of higher social status acquired newly built housing of higher quality with a better access to infrastructure (Dangschat \& Blasius, 1987). Yet, the barriers between the social strata were generally not too rigid, i.e. people of different status could still be living side by side in the same houses and neighborhoods (Vendina, 1997).

In the post-socialist period, with the loosened state control, households received unprecedented freedom in housing choices. It became possible to make an individual choice, which was driven by the households' needs and desires (Clark, 2009; Mulder \& Wagner, 1998). The individual needs and desires vary depending on the households' life course stage, socio-economic background, and cultural orientation (Clark, Deurloo, \& Dieleman, 1984; Kährik, Temelová, Kadarik, \& Kubeš, 2016). The choice of housing is therefore influenced by infrastructural and spatial characteristics of the area: the accessibility of amenities, workplaces, distance to family members and friends (Kährik et al., 2012; Karsten, 2007). The reputation and perceived image of the area are also important in making residential choices (Sørensen, 2014). Naturally, income inequalities play a crucial role mediating these choices (Gentile, 2015; Marcińczak, 2012; Marcińczak, Musterd, \& Stępniak, 2012) and limiting the opportunities for low income households (Kährik et al., 2012, 2016; Musterd et al., 
2015). Thus, the development of socio-spatial structures within post-socialist capital cities is characterized by contradictory processes (A. Smith \& Timár, 2010). Some districts face hominization, i.e. ghettoization of the rich and the poor citizens, while the others face heterogenization, i.e. newly built or renovated elite housing estates attracting high-income households could be located in the proximity of crumbling and abandoned buildings (Gdaniec, 2005). Yet, the inequalities formed under socialism, e.g. variable housing quality, differences in service provision, reputation and prestige of certain districts, are the starting point for shaping inequalities under market conditions (D. M. Smith, 1996). And these preset inequalities are still largely visible, as urban development is largely limited by historical inertias (Vendina, 2013).

Migrant households that make their first residential choice within the city of destination are no exception to the above guidelines; they choose housing according to personal preferences and available resources. However, the association of migrants' first residential choices and housing prices is complicated: both way influence could be argued (Mulder, 2006). For example, analyzing 20 cities of Italy, Accetturo, Manaresi, Mocetti, \& Olivieri (2014) found that in-migration raises average housing prices at the city level, while it reduces price growth in the districts mostly affected by migration inflow.

For particular migrant groups, such as temporary labor migrants, housing prices may play even a more important role. Not only they delimitate their housing choices, but also define whether to move alone or together with their families (Demintseva \& Peshkova, 2014). The residential patterns of ethnic minority populations (mainly immigrants from other countries) may be influenced not only by housing prices but also by the housing market discrimination that impose additional restrictions on the residential choice (Bolt \& Van Kempen, 2010). As long as the inflow of migrants to postsocialist capitals is largely fostered by economic stimulus such as unemployment or low wages in the areas of out-migration (Fischer-Tahir \& Naumann, 2013; Hess et al., 2012), it is natural to assume that migrants may prefer less prestigious, relatively cheap neighborhoods and districts, at least at the moment of the first residential choice. In line with this argument, the inflow of migrants would then contribute to the social-spatial polarization of the city structure, since areas of migrant concentration would increasingly become low income enclaves. 


\section{MOSCOW CONTEXT}

Moscow consists of 125 city districts grouped into 10 okrugs $^{2}$ (Fig. 1A). The average population size of a district was 92 thousands, according to the Russian Census 2010 (Federal State Statistics Service, 2010); yet, there is an evident spatial regularity with the peripheral districts being more populated than the central ones (Fig. 1B). One explanation is that the majority of buildings in the central districts are used for offices. Another explanation refers to the varying building types. In the late Soviet period, when Moscow was rapidly expanding, the peripheral districts were built up with large multi-storeyed buildings, which resulted in formation of the densely populated sleeping quarters (Makhrova et al., 2013).

A

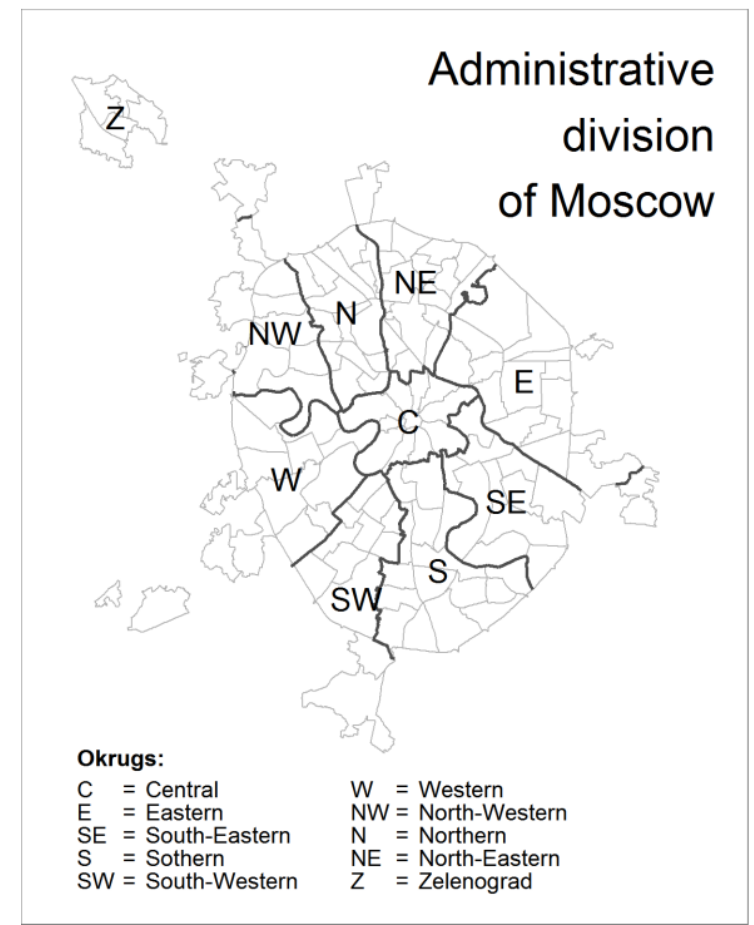

B

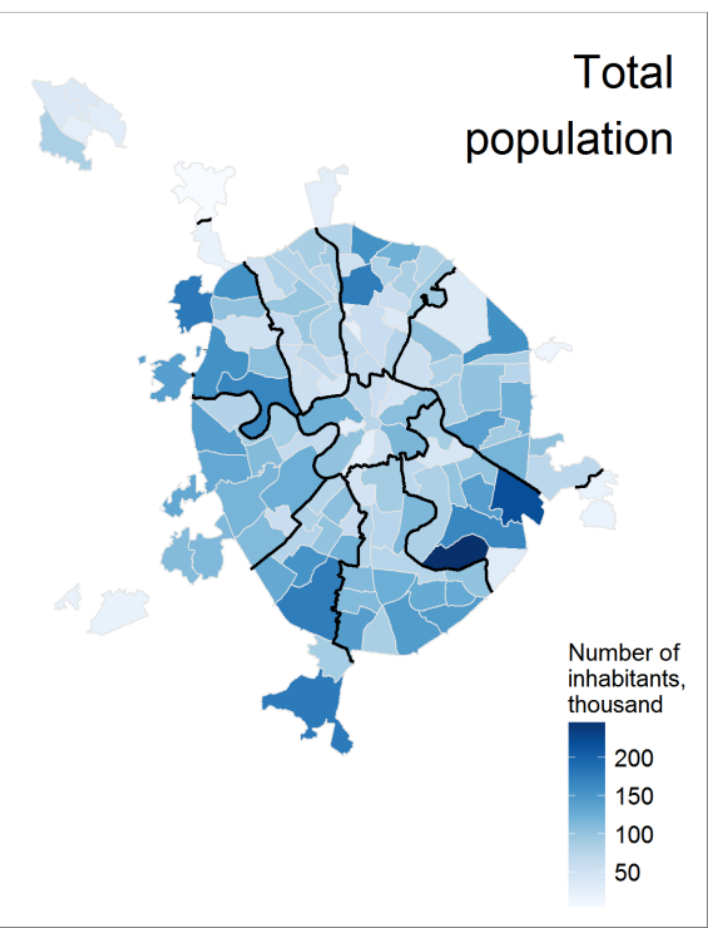

Fig. 1. Descriptive maps of Moscow districts: (A) reference map of administrative division; (B) total population by districts. Source: (Federal State Statistics Service, 2010).

The urban economy of Moscow has adapted quite quickly to the new market conditions, Vendina (1997, p. 350) argues: "already in the late Soviet times it embarked on a road of postindustrial development, when prerequisites were created for restructuring the economy, especially through a more active growth of foreign economic, finance and credit, trade and mediation activity."

\footnotetext{
2 In July 2012 there was a major administrative reform in Moscow which resulted in almost 2.5 times increase in the area of the city. 21 new districts grouped in 2 okrugs were cut of Moscow oblast (the region surrounding Moscow). Not much data is available for the sparsely populated new districts. In this paper we analyze Moscow in the administrative borders before the reform of July 2012.
} 
Nowadays the main sectors of employment in Moscow are trade, real estate transactions, and construction; in 2012 they accounted for 25, 18, and 13\%, correspondingly, of the employed population of Moscow (Federal State Statistics Service, 2013). As mentioned in the introduction, economic stimulus, namely employment, is among the main reasons for in-migration to Moscow. The urban economy of Moscow is becoming more and more dependent on migrant labor, and some sectors are more dependent than the others. The spheres of high-qualified employment in Moscow are more competitive than low-skilled. Thus, often migrants, especially from CIS countries, occupy the jobs, that the local population prefers to ignore. As the result, migrants in Moscow are mainly employed in low-paid and low-prestige jobs, such as construction, trade, and various service industries (Tyuryukanova, 2009). The spatial projection of employment and income differentiation, including the employment of migrants, is reflected in the growth of the contrasts in residential choices and the dependency between the level of welfare and the prestige of residential area (Makhrova \& Golubchikov, 2012).

A

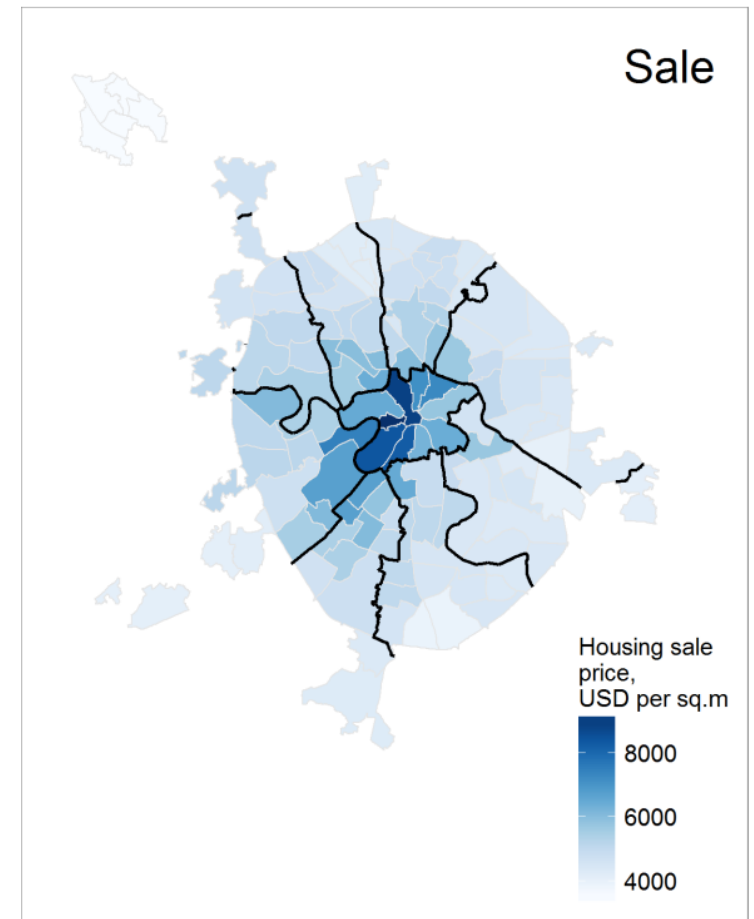

B

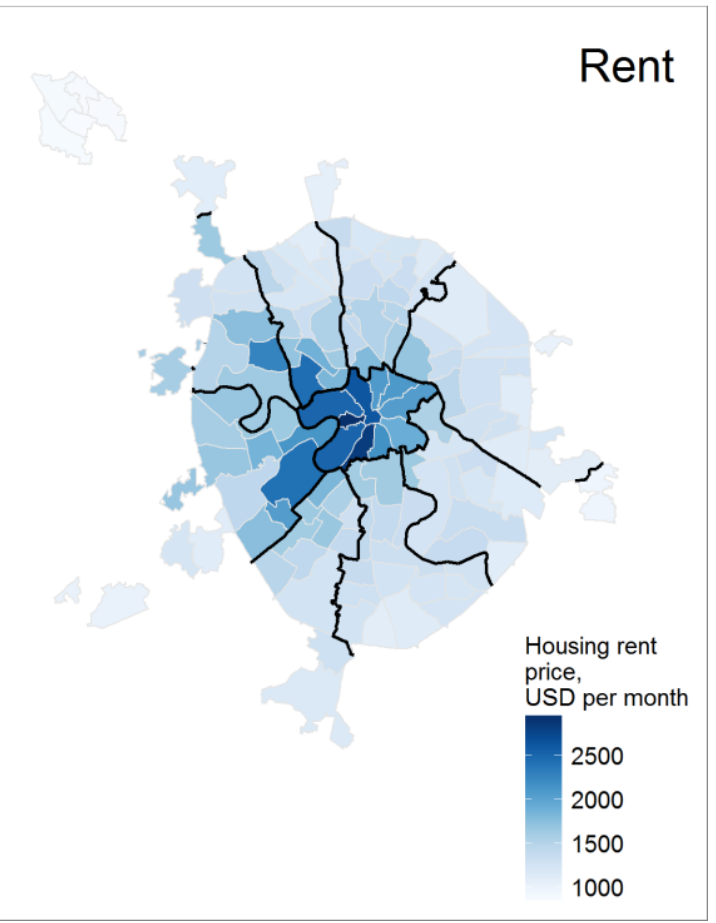

Fig. 2. Spatial variation of housing prices in Moscow in 2012: (A) sell price; (B) rent price. Source: (A) RBC (RBC, 2013); (B) CIAN (CIAN, 2012).

Note: To transform the prices from RUB to USD, we use the currency exchange rate on 30 June 2012.

The clearly visible spatial patterns of housing prices reflect to some extent the prestige of the okrugs and districts (Fig. 2). The two main regularities in the formation of housing prices are 
evident. First, there is a strong negative correlation between housing prices and the remoteness from the city center. The price gap between the central and remote districts increases steadily (Makhrova \& Nozdrina, 2002). Unlike many Western cities, Moscow does not have prestigious suburbs. This is a long-lasting preference of Moscow citizens that was previously noted. For example, Alden, Beigulenko, \& Crow (1998, p. 373) write: "culture of central living is extremely strong, despite the high pollution in the city center". Second, the Western part of the city is more prestigious and expensive than the Eastern part (Bater, 2001; Kirillov \& Makhrova, 2012; Makhrova, 2006; Popov, 2014). This regularity of settlement is quite usual for continental Europe. The underlying explanation is purely geographical. The main wind direction is Western because of Prevailing Westerlies. Historically manufactures were mainly located in the Eastern part of the city. Thus, those who could afford it struggled to settle in the Western part. Today, the Eastern and Southern districts of the capital are perceived as low-prestige and even marginal (Vendina, 2013).

Over $30 \%$ of Moscow real estate were constructed in the post-soviet times (Makhrova \& Golubchikov, 2012). Despite the considerable pace of new construction, the issue of housing affordability is not nearly resolved; and the chaotic construction under the large surplus of the demand over the supply results in the creation of less human urban environment (Makhrova \& Golubchikov, 2012; Vendina, 2009). New elite houses, that are usually gated like fortresses, are built in the central and sub-central parts of the city, primarily in the Western and to a lesser extent in the Northern districts; that results in the expansion of the prestigious central residential area (Trubina, 2011; Vendina, 2013), while the more affordable housing is constructed mainly in the remote districts of Moscow. 


\section{DATA, \& METHODS}

\section{Data}

This paper uses data on Moscow migration form a recently published Rosstat Municipal Database (Federal State Statistics Service, 2012). The data represent numbers of migrants in 2012 disaggregated by two hierarchical spatial levels (okrugs and districts) and four characteristics of migration flows (Table 1).

\section{Table 1. Characteristics of migration flows}

\begin{tabular}{|c|c|}
\hline $\begin{array}{l}\text { Characteristics of } \\
\text { migration flows }\end{array}$ & Levels \\
\hline Type (5) & $\begin{array}{l}\text { Whole migration } \\
\text { Migration between regions of Russia } \\
\text { International migration } \\
\quad \text { - exchange with CIS } \\
\quad \text { - exchange with other countries }\end{array}$ \\
\hline Direction (3) & $\begin{array}{l}\text { Saldo } \\
\text { In } \\
\text { Out }\end{array}$ \\
\hline $\operatorname{Sex}(3)$ & $\begin{array}{l}\text { Both } \\
\text { Female } \\
\text { Male }\end{array}$ \\
\hline Age (18) & $\begin{array}{l}\text { Total } \\
\text { From } 0 \text { to } 4 \\
\ldots \\
\text { From } 75 \text { to } 79 \\
80 \text { and older }\end{array}$ \\
\hline
\end{tabular}

The data have some limitations. First, there is a mismatch between the total numbers of inmigrants as computed by summing up the Fig.s for all districts and the aggregated data published for the whole Moscow. According to aggregated data, 205.5 thousand persons were registered within the city in 2012. The summation of district-specific data gives only 183.3 thousand. One of the reasons for the discrepancy in the in-migration records is that a migrant can be registered not only according to the actual place of residence within the city, but also by an employer without any reference to a specific district. Second, the data only include the information on legal migrants. Both researchers (Shmatko, 2014; Tyuryukanova, 2009; Vakulenko \& Tsimaylo, 2011) and city government officials (Ekho Moskvi, 2008) agree that the volume of illegal migration to Moscow may be very high. Unfortunately, there are no precise and transparent estimates of the number of unregistered migrants; and, of course, such estimates are not available at the level of city districts. Thus, we have to neglect this part of in-migration to Moscow in our analysis.

\footnotetext{
3 There were 83 regions in Russia in 2012. Moscow has the official status of a region (federal unit).
} 
To compute age-specific migration rates, we use age structure as captured by Russian Census 2010 (Federal State Statistics Service, 2010). Of course, the demographic structure at the moment of Census (14 October 2010) was not the same as it became by 1 January 2012. Yet, we had to assume this equality due to the absence of demographic structure estimates and vital and migration statistics for 2011. This data limitation reduces the preciseness of the estimates of the age-specific migration rates, but this effect is quite moderate and cannot affect migration patterns strongly.

Data on housing prices distribution across Moscow districts were taken from two sources. The first are monthly ratings of Moscow districts by average housing sale prices (measured in USD per square meter) published by $\mathrm{RBC}^{4}(\mathrm{RBC}, 2013)$. These ratings are based on $\mathrm{IRN}^{5}$ data. The second data source is average monthly rental prices (measured in RUR) in 2012 collected from CIAN 6 interactive map of real estate prices (CIAN, 2012). These data are based on statistics of rental contracts signed in 2012 and indexed by CIAN database. The quality of the housing prices data is not alarming, as the estimates are based on big samples and are unlikely to be inaccurate.

\section{Methods}

To compare the intensities of in-migration flows we use Poisson regression which is known to perform better than linear ordinary least squares models dealing with low intensity rates or rates of events happening in a small population (Frome, 1983). This feature of Poisson regression is important for the design of our study because, even after the generalization of age groups, migration intensities are very small for some partial flows in many districts. Poisson regression models are also implemented to find the association between in-migration rates and housing prices. To assess the explanatory power of the regressors, we use analysis of variance (Welch, 1951). Spatial hierarchical decomposition of Theil's index of inequality (Theil, 1979) is applied in order to Fig. out the most heterogeneous age group in terms of spatial variation of in-migration rates.

For the data preparation, analysis and visualization we used $R$, a language and environment for statistical computing ( $\mathrm{R}$ Core Team, 2016). Additional packages were used: (i) for data manipulations, dplyr (Wickham \& Francois, 2015), tidyr (Wickham, 2016b); (ii) for visualization, ggplot2 (Wickham, 2016a), rgdal (Bivand, Keitt, \& Rowlingson, 2015), viridis (Garnier, 2016), cowplot (Wilke, 2016).

\footnotetext{
${ }^{4}$ Russian Business Consulting (www.rbc.ru)

${ }^{5}$ Indicatori Rinka Nedvizhimosti (Indicators of Real Estate Market, www.irn.ru).

${ }^{6}$ Tsentr Informcii i Analitiki Nedvizhimosti (Centre for Real Estate Data and Analytics, www.cian.ru)
} 


\section{COMPARISON OF MIGRATION FLOWS’ INTENSITIES}

\section{Variation by type of migration flow}

Migration intensities are distributed unevenly by the types of migration flows (Fig. 3). The whole migration to Moscow is mainly described by between regions movements rather than by international migration. Similarly, immigration to Moscow from abroad is mainly about exchange with CIS (Fig. 3A).
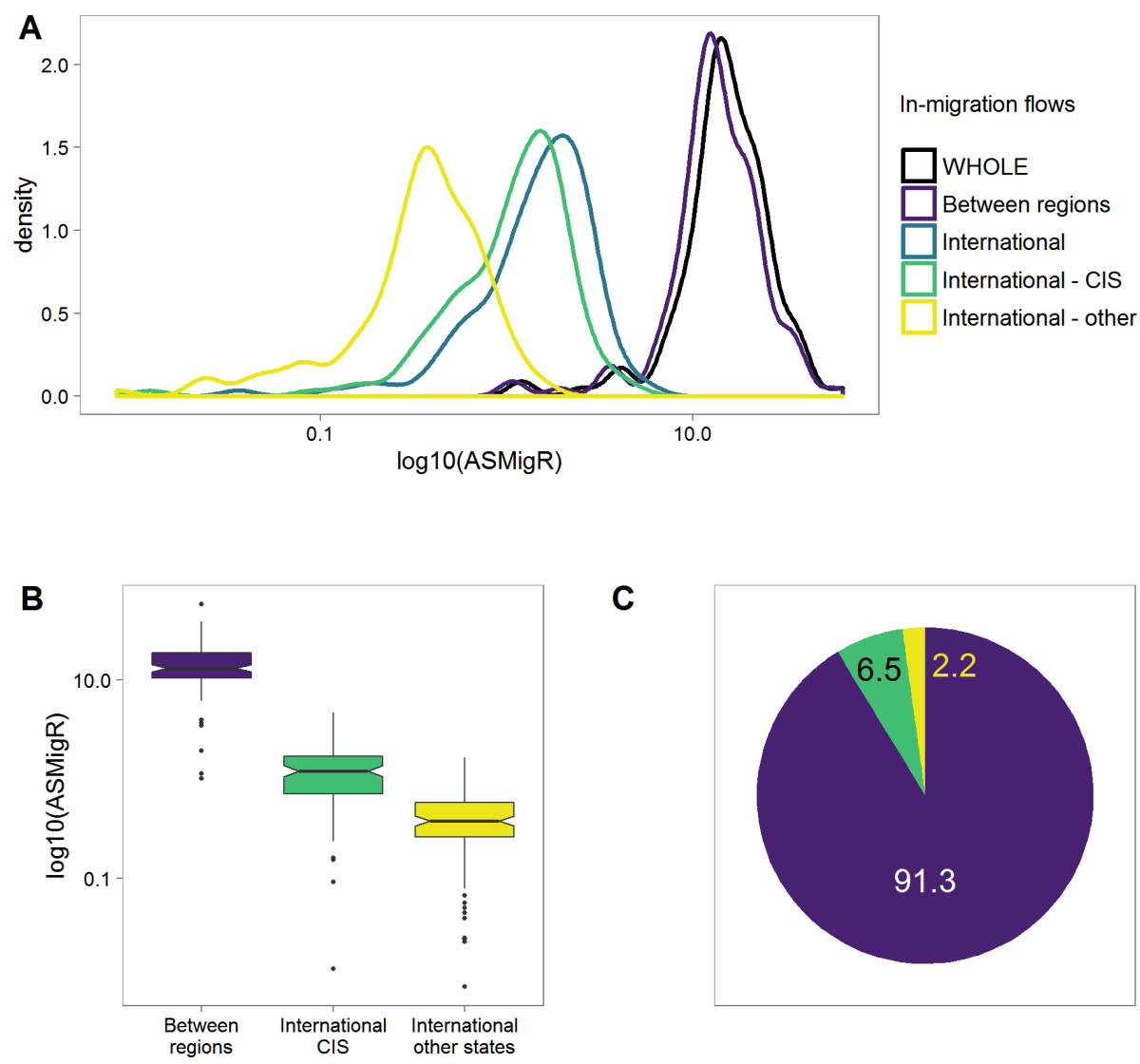

C

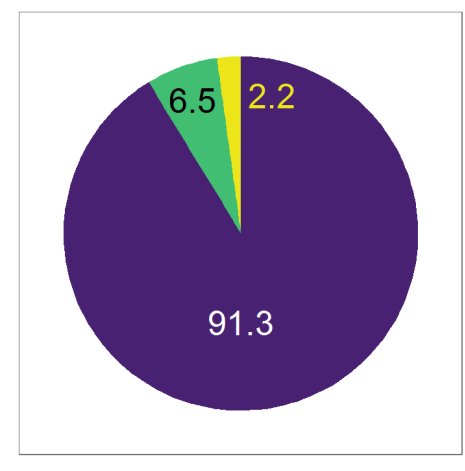

Fig. 3. Density (A), box (B), and pie (C) plots of in-migration flows (both sex, total age group) by type of migration

flow. Note: two types of international migration (from CIS and from other countries) add up to general international migration; between regions and international migration flows add up to whole migration.

To compare intensities formally, we perform Poisson regression controlling for age and sex; reference category for types of flows is whole migration. As it is precisely the sum of all partial flow intensities $^{7}$, between regions and two types of international; the odds ratios (OR) of these partial flows intensities add up to 1 . Thus, using Poisson regression we estimate the contribution of each type of migration flow controlling for age and sex (Fig. 3C). Between regions migration is

\footnotetext{
7 This is true, because each partial flow's intensity is computed by relating the partial number of migrants to the constant mean population of a city district. The similar logic is not applicable for age and sex because computing ratios for specific age and sex imply relation of partial number of migrants, i.e. to age- and sex-specific populations of city districts.
} 
responsible for $91.3 \%$ of all in-migration to Moscow. The rest $8.7 \%$ stand for international migration and is unevenly divided between inflow from CIS (6.5\%) and inflow from all other countries (2.2\%).

\section{Variation by age and sex}

Age variations of migration intensities are, of $\operatorname{course}^{8}$, considerable. Interestingly, there is a notable diversity of age profiles by type of migration flow (Fig. 4A). We compare age profiles of inmigration flows separately for each type of migration flow, controlling for sex; the reference age group is total. Between regions migration differs from international mostly at "student ages". The biggest migration influx to Moscow from other regions of Russia is registered at the age group 15-19 - student ages. Of course, not all of these migrants are students, but the recent estimates indicate that the majority of them are (Kashnitsky, Mkrtchyan, \& Leshukov, 2016). Moscow is a major educational center in Russia; yet it is not recognized as one of the world leading educational centers. Thus, the international student migration to Moscow is quite limited, most of the immigration from the foreign countries occurs at the ages a bit older than student.
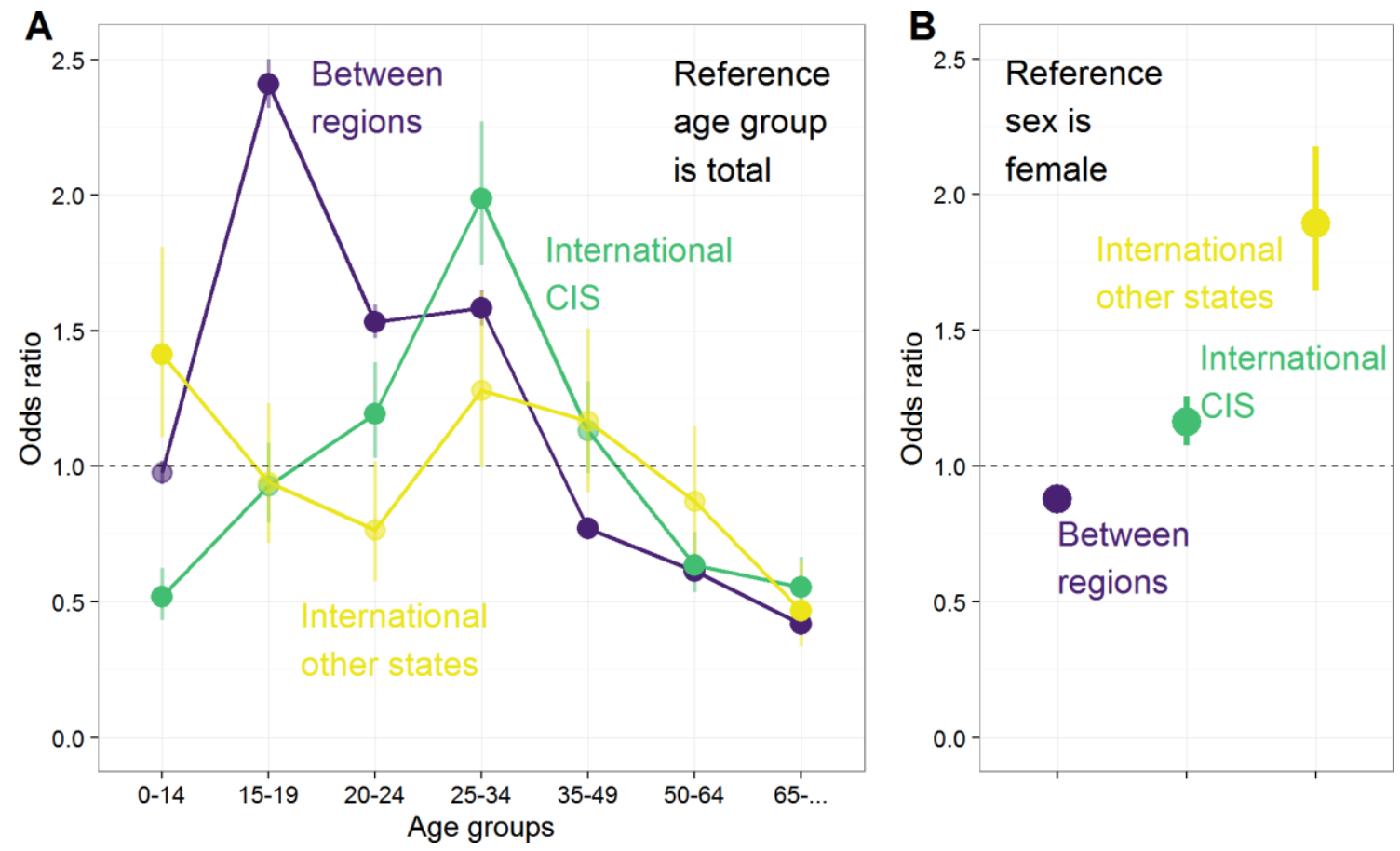

Fig. 4. The effect of age (A) and sex (B) on in-migration to Moscow by type of migration flow. Note: for each type of migration flow a separate Poisson regression model was built; models are controlled for sex and age, correspondingly; vertical ticks represent $95 \%$ confidence intervals; in panel A, statistically significant ORs are marked with solid dots.

\footnotetext{
8 Age selectiveness of migration is well known and is observed on virtually any migration data. See for example (Pittenger, 1974) or (Castro \& Rogers, 1983).
} 
Immigration from CIS is highly concentrated at prime working ages. These migrants mainly occupy low ranked jobs and earn just enough to survive and send some money back to their families in the counties of origin. According to Demintseva \& Peshkova (2014), up to $70 \%$ of adult migrants from Middle Asia share one room between 3-8 people. No wonder, three quarters of them have no children in Moscow though only less than $30 \%$ of them claim they have no children at all. Our results strongly support these findings. For international immigration from CIS, OR for children aged 0-14 is 0.52 in comparison with total. All in all, it seems that migrants from CIS with relatively low socio-economic status cannot afford to move to Moscow with their children. The opposite is true for immigration from other countries. As already shown above, the intensity of immigration form countries other than CIS is negligibly low (about $2 \%$ of all in-migration). This minor group of migrants is mainly represented by diplomats and consular workers. Of course, these people are of relatively high socio-economic strata. As could be seen from the age distribution of this migration flow, immigrants from non-CIS countries tend to move to Moscow at rater mature ages and with children, though for the prime working ages differences in migration intensities by age are not statistically significant.

Inequality of migration intensities by sex is quite moderate when the whole migration is considered. The OR for men is $9.5 \%$ lower comparing with women as a reference and controlling for type of migration flow and age. This finding corresponds with the basics of Ravenstein-Lee theory of migration (Lee, 1966; Ravenstein, 1885). One of the "laws of migration" states that women are more active in short-distance migration while men dominate in long-distance moves. In practice, empirical evidence for this law is usually found in distinction between internal (short-distance) and international (long-distance) migration ${ }^{9}$. In-migration to Moscow is mainly described by internal migration (between regions) in which women dominate (Fig. 4B). A separate model for internal migration shows even lower participation of men; OR for men is $13.6 \%$ lower comparing with women as a reference and controlling for age. The regression model for international migration flows provides further support for the "international" part of Ravenstein-Lee law. OR for men in international migration is $29.5 \%$ higher. Though, international in-migration flow is quite heterogeneous. There is lower predominance of men among migrants from CIS, 15.3\%. For immigration from all other countries OR for men is $86.2 \%$ higher.

${ }^{9}$ Distance here should be broadly considered as the cumulative cost of migration rather than physical distance. 


\section{Spatial variation}

To analyze spatial variation of in-migration rates, we run Poisson regressions including dummies for districts and okrugs. The mapped ORs represent migration intensity at a given district /okrug in relation to the average intensity for the whole Moscow and controlling for sex and age (Fig. 5). For each of the migration types a separate model was built; all regression models were built separately at the levels of districts and okrugs.
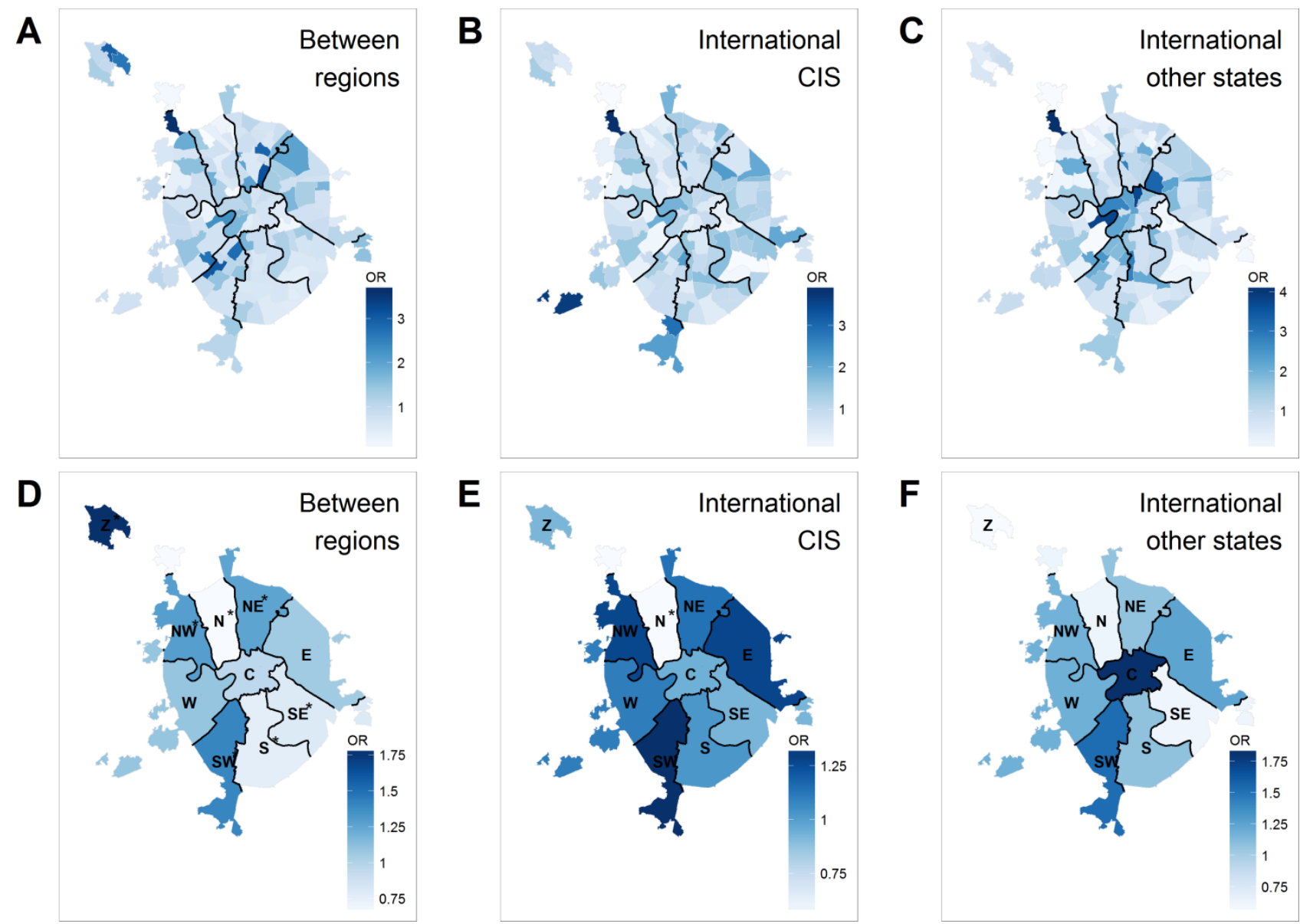

Fig. 5. Spatial variation of in-migration to Moscow by type of migration flow and spatial levels: city districts (AC), okrugs (D-F). Note: mapped values represent ORs from Poisson regression models; for each type of migration flow a separate model was built; models are controlled for sex and age; reference is the whole Moscow; statistical significance at $95 \%$ confidence interval for okrugs is marked by a star.

In general, spatial variation tends to be statistically significant for internal migration. Less districts experience international immigration at a rate statistically different from the intensity for the whole Moscow. Keeping statistical significance in mind, we would like to highlight two extreme differences between types of migration flows. First, for between regions migration the symptomatic phenomenon is the high OR for the okrug of Zelenograd, while international migrants are not 
attracted by this remote okrug of Moscow. Probably, this difference may be explained with varying housing strategies. Our intuition is that internal migrants are more likely to buy houses while international migrants prefer to rent apartments. Housing prices are much lower outside Moscow Ring Road (MKAD) ${ }^{10}$. Popov (2014) reports a 20-25\% drop in housing prices with the crossing of the Moscow city border. Probably, this factor is much more important in attraction of property buyers rather than tenants. Second, for immigrants from non-CIS countries ORs for settling in the central city districts are higher. This fact indicates that non-CIS migrants may be of a higher socioeconomic status. If the hypothesis of the higher socio-economic status of immigrants from non-CIS countries is true, our finding strongly correlates with those of White (1998) who found that immigrants from the developed world settle densely in the center of London. The reasons for such a clustering may be not only pure economic. Other factors in favor of central location might be language issues and security considerations. The center of Moscow is quite international and, thus, suits better for those migrants who do not speak Russian: due to language limitations international migrants might favor to live close to other foreigners to be able to form social contacts. As a result, immigrants from non-CIS countries might be willing to pay quite an extra sum for their housing to ensure that they live in an area where they can establish social contacts and perform daily activities.

One may notice that okrugs appear to be quite heterogeneous. The decomposition of Theil's index of inequality helps to identify which part of spatial variation in migration intensities could be attributed to inequality between okrugs, and which is caused by inequality within okrugs (Fig. 6).
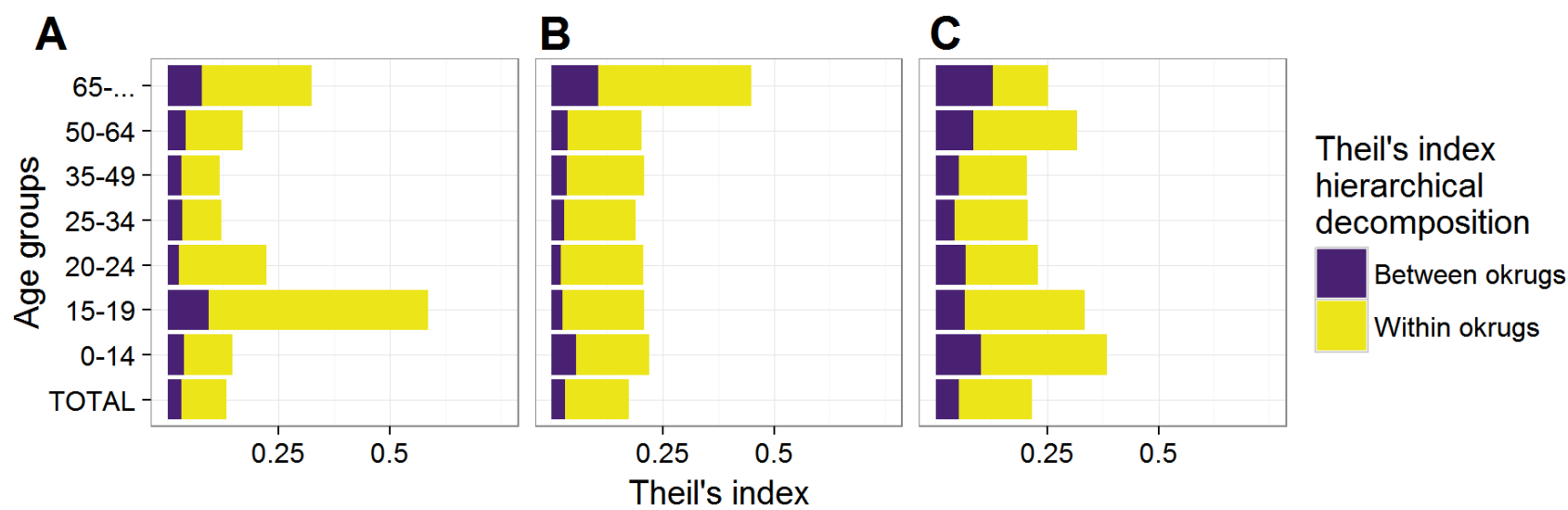

Fig. 6. Hierarchical decomposition of Theil's index of inequality in in-migration rates by types of migration flows: between region (A), international from CIS (B), and international from other countries (C).

\footnotetext{
${ }^{10}$ Moscow Ring Road is a big motorway that was opened in 1961. At that moment MRR encircled the whole territory of Moscow. In Russian: Moskovskaya koltsevaya avtomobil'naya doroga.
} 
Three main outputs could be derived from the inequality analysis. First, within okrugs inequality is much bigger than between okrugs inequality. That means that okrugs are quite heterogeneous. In other words, it is difficult to draw strong conclusions about spatial variation of inmigration analyzing data only at the spatial level of okrugs. Second, lower intensities of migration cause bigger inequality because a considerable number of districts do not experience any inmigration. This is particularly true for international migration flows. Finally, the biggest inequality in migration intensities is a feature of internal migration at the ages of $15-19$, and this inequality is mainly within okrugs. That means, a limited number of districts attract the biggest share of all internal migrants aged 15-19. Such a high level of inequality means that there is a factor explaining large share of variance in settlement patterns of these particular migrants.

As the migrants aged 15-19 are mainly students, their settlement pattern should be driven by the location of student dormitories. To our knowledge, there is no open data base on student dormitories. So we composed the list of student dormitories that are affiliated with the largest Moscow universities. We collected data on 82 buildings located in 46 districts. Using these data, we composed a dummy variable showing presence of student dormitories in districts. Of course, one would want to use the data on all student dormitories within city boundaries, ideally accounting for the capacity of each building. But such detailed data are not available. Nevertheless, even a roughly composed dummy variable proves to be very useful as it explains a notable share of variance (14.5\%) in in-migration rates of those aged 15-19. The presence of one or several student dormitories in a district almost triples the inflow if youths aged 15-19 $(\mathrm{OR}=2.83)$. Interestingly, this is only true for internal migration, which accounts for $95.6 \%$ of all the inflow to Moscow at ages 15-19. International migration to districts with student dormitories is not statistically higher than to "nonstudent" districts. 


\section{DO HOUSING PRICES MATTER?}

Data on housing sale and rent prices gathered from different sources show very similar spatial patterns ( $\mathrm{R}=0.895$, see Fig. 2). Probably, the lack of big difference between spatial variation of sale and rent housing prices is caused by the large volume of Moscow housing rent market. In fact, both housing prices variables are almost identical in explaining variation in migration rates. Thus, we provide the results of modeling only for one of them, sale prices (Fig. 7).

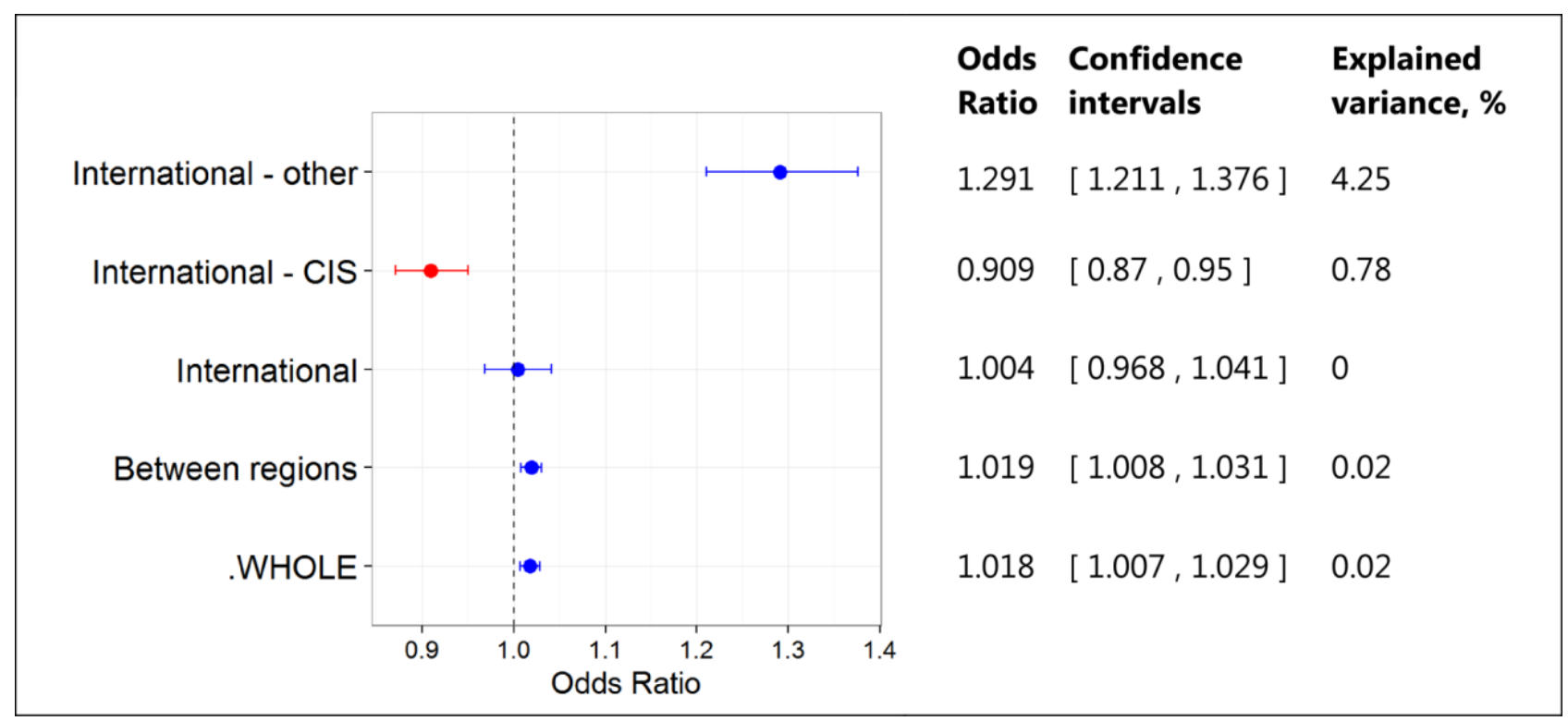

Fig. 7. The effect (ORs) of housing sale prices on in-migration to Moscow by type of migration flow. Note: for each type of migration flow a separate Poisson regression model was built; regressor is the logarithm of housing sale prices; models are controlled for sex, age, and presence of student dormitories; horizontal lines represent $95 \%$ confidence intervals for ORs; color stands for the effect: blue - positive, red - negative.

The effect of housing sale prices on in-migration to Moscow is statistically significant for all types of migration flows except for the total international one. Though, the explanatory power of the regressors is quite low. Only for non-CIS countries housing prices explain more than $1 \%$ of the variation in migration intensities across city districts ("Explained variance" column of table in Fig. 5). One standard deviation increase in housing sale price (1086 USD per sq. $\mathrm{m}$ ) is associated with $29.1 \%$ increase in the intensity of immigration from far-away countries.

Quite opposite effect housing prices cast on the intensities of immigration from CIS. One standard deviation rise in housing prices corresponds to a $9.1 \%$ reduction in immigration from CIS rates. The difference between two categories of international in-migration supports the idea of varying socio-economic characteristics of immigrants.

The effect of housing prices on internal migration is very limited. A standard deviation increase in housing prices corresponds to $1.9 \%$ increase in internal migration intensity. This weak 
positive association is still surprising. As mean wages in Moscow are higher than in the rest of the country (Zubarevich, 2012), with the lower incomes of internal migrants the overall effect of housing prices on in-migration rates should be negative. However, the difference in house quality and price within district could be much higher than the difference among districts (Bater, 2001; Demintseva \& Peshkova, 2014), For instance, some districts offer affordable economy class housing on the secondary market, while the primary market provides expensive high class housing; as the result, mean value is not very meaningful. This heterogeneity and imbalance of housing prices hinders the analysis even at the district level. Generally, prestige of a district is still a better predictor for inmigration flows than housing prices. 


\section{DISCUSSION AND CONCLUSION}

The intensities of in-migration to Moscow are very unevenly distributed by the lands of origin. Migration from regions of Russia accounts for $91.3 \%$ of all the inflow to Moscow. Of the rest $8.7 \%$, international migration from CIS holds three quarters, immigration from all non-CIS countries constitute only $2.2 \%$ of the whole in-migration. The inflow of internal migration is the youngest, as its big portion is constituted by students; women dominate in internal migration. International migrants are on average older; among these migrants, men dominate.

The spatial patterns of in-migration vary by type of migration flow, i.e. the types of origin territories. Both internal migrants (from other Russian regions) and immigrants from CIS tend to prefer less prestigious locations in the southern and eastern parts of the city, although the areas of the high concentration of these two migrant groups differ. This regularity supports the hypothesis of the relatively low income that limits their residential choice largely. Besides the choices of CIS migrants are also to some extent dictated by the discrimination in the housing market, the phenomenon that was mentioned earlier in the literature review. The evidence of discrimination was found by Ashkenazi \& Vakshtein (2009) when analyzing the rent advertises containing phrases as "only Russian", "only Slavs", "except from the Caucasus", " except from Asia" and so on. The results of our analysis, in line with the arguments of Demintseva \& Peshkova (2014), Vendina (2013), Ashkenazi \& Vakshtein (2009), suggest that immigrants from CIS reside in the most deprived districts, e.g. the regions with high crime rates, worst environmental, and infrastructural conditions. In contrast, non-CIS immigrants tend to settle in the more prestigious central districts. These general preferences indicate that there is a socio-economic differentiation between internal migrants, CIS and non-CIS immigrants. The latter seem to be of a higher socio-economic status. One of the major disturbance factors of the analysis is the presence of student dormitories. Student migration constitutes a notable share of internal inflow to Moscow. Thus, the location of the biggest student dormitories in the most prestigious districts, which is often the case in Moscow, blurs the sharpness of the spatial pattern of the first residential choices.

Empirical evidence from the Western cities suggests that housing prices and the first residential choices are interrelated, at least regarding immigrants (Bolt, Hooimeijer, \& Van Kempen, 2002; Musterd, 2005; Musterd \& Van Kempen, 2009; Van Ham \& Manley, 2009). Generally, higher housing costs reduce the likelihood that a particular location within a city is selected (Plantinga, Détang-Dessendre, Hunt, \& Piguet, 2013). However, housing prices in Moscow have limited association with in-migration intensities, i.e. migrants' first residential choices, at least when the analysis is conducted at the level of city districts. Although statistically significant association between housing prices and migration intensities usually exists, variance explained by the 
explanatory variable is very limited. There are few possible explanations for that. First, internal migrants have more opportunities regarding residential choices that are not associated with their income, e.g. students can stay in dormitories or with their relatives (Yashunsky \& Zamyatina, 2012) thus residing within the high housing price districts. Second, residential choices of internal migrants may be to a higher degree shaped by other factors, such as proximity to work or educational facility. The fact that a considerable effect of housing prices is only evident for residential choices of the highly diverse international migrant group strongly supports both of the above hypotheses. Third, the prestige of some districts still means much more than the objective characteristics of housing (Rudolph \& Brade, 2005; Vendina, 1997), and contributes largely to the formation of the mean housing prices (Popov, 2014). However, housing prices may vary greatly within the district due to the objective characteristics of the houses and the infrastructure. Such a mixed housing landscape is characteristic of many post-socialist cities (Marcińczak, Gentile, Rufat, \& Chelcea, 2014; Sýkora, 2009). Under such conditions the average housing prices become a poor predictor even at the district level.

The obtained results on migrants' first residential choices provide evidence that, to some extent, the process of residential socio-spatial differentiation is going on in Moscow. There are clearly some districts that attract more migrants of specific status and ethnicity than others. But the spatial patterns of residential choices correspond more with the prestige of localities and not the housing prices, which seem to vary a lot on an intra-district level. Taking this into account, a more detailed data on in-migration and housing prices is needed to investigate the evolution of the city's socio-spatial structure on the inner district level. Migrants may reside somehow evenly within the districts producing heterogenic socio-spatial structures or segregated at the level of neighborhoods. Regarding the level of city districts, our research suggests that the spatial polarization of the city structure produced by the residential choices of the in-comers to Moscow is quite low. It is clear that further, more detailed research in this direction is needed; however, it would only be possible with the publication of new statistical data.

\section{ACKNOWLEDGEMENTS}

Support from the Basic Research Program of the National Research University Higher School of Economics is gratefully acknowledged. We also appreciate help from Sebastian Klüsener, Leo van Wissen, Joop de Beer, Nadir Kinossian, Isolde Brade, Ekaterina Demintseva, Olga Choudinovskikh, ira.urban project team, and the anonymous reviewers. 


\section{REFERENCES}

Accetturo, A., Manaresi, F., Mocetti, S., \& Olivieri, E. (2014). Don't stand so close to me: The urban impact of immigration. Regional Science and Urban Economics, 45, 45-56. http://doi.org/10.1016/j.regsciurbeco.2014.01.001

Alden, J., Beigulenko, Y., \& Crow, S. (1998). Moscow: Planning for a world capital city towards 2000. Cities, 15(5), 361-374. http://doi.org/10.1016/S0264-2751(98)00031-6

Andrienko, Y., \& Guriev, S. (2004). Determinants of interregional mobility in Russia. The Economics of Transition, 12(1), 1-27. http://doi.org/10.1111/j.0967-0750.2004.00170.x

Ashkenazi, L., \& Vakshtein, M. (2009). Natsionalnie predpochteniya pri arende jilploshadi v Moskve (Ethnic preferences for rental housing in Moscow). Demoscope Weekly, (389-390). Retrieved from http://www.demoscope.ru/weekly/2009/0389/analit02.php

Bater, J. H. (2001). Adjusting to change: privilege and place in post-Soviet central Moscow. The Canadian Geographer/Le Géographe Canadien, 45(2), 237-251. http://doi.org/10.1111/j.1541-0064.2001.tb01486.x

Bivand, R., Keitt, T., \& Rowlingson, B. (2015). rgdal: Bindings for the Geospatial Data Abstraction Library (Version 1.1-3). Retrieved from https://CRAN.R-project.org/package=rgdal

Bolt, G., Hooimeijer, P., \& Van Kempen, R. (2002). Ethnic segregation in the Netherlands: new patterns, new policies? Tijdschrift Voor Economische En Sociale Geografie, 93(2), 214-220.

Bolt, G., \& Van Kempen, R. (2010). Ethnic Segregation and Residential Mobility: Relocations of Minority Ethnic Groups in the Netherlands. Journal of Ethnic and Migration Studies, 36(2), 333-354. http://doi.org/10.1080/13691830903387451

Borén, T., \& Gentile, M. (2007). Metropolitan processes in post-communist states: an introduction. Geografiska Annaler: Series B, Human Geography, 89(2), 95-110.

Brasington, D. M., Hite, D., \& Jauregui, A. (2015). House Price Impacts of Racial, Income, Education, and Age Neighborhood Segregation. Journal of Regional Science, 55(3), 442-467. http://doi.org/10.1111/jors.12173

CIAN. (2012). Map of real estate prices in Moscow. Retrieved March 15, 2015, from http://stat.cian.ru/rent/2012

Clark, W. A. V. (2009). Changing Residential Preferences across Income, Education, and Age Findings from the MultiCity Study of Urban Inequality. Urban Affairs Review, 44(3), $334-355$. http://doi.org/10.1177/1078087408321497

Clark, W. A. V., Deurloo, M. C., \& Dieleman, F. M. (1984). Housing Consumption and Residential Mobility. Annals of the Association of American Geographers, 74(1), 29-43. http://doi.org/10.1111/j.1467-8306.1984.tb01432.x

Dangschat, J., \& Blasius, J. (1987). Social and spatial disparities in Warsaw in 1978: An application of correspondence analysis to a socialist city. Urban Studies, 24(3), 173-191.

Demintseva, E. B., \& Peshkova, V. M. (2014). Migranti iz Srednej Azii v Moskve (Migrants from Middle Asia in Moscow). Demoscope Weekly, 597-598. Retrieved from http://demoscope.ru/weekly/2014/0597/tema01.php

Denissenko, M. B., \& Stepanova, A. V. (2013). Dinamika chislennosti naseleniya Moskvi za 140 let (Dynamics of Moscow population over 140 years). Vestnik MSU. Economics, 3, 88-97.

Ehrlich, K., Kriszan, A., \& Lang, T. (2012). Urban Development in Central and Eastern Europe - Between Peripheralization and Centralization? disP - The Planning Review, 48(2), 77-92. http://doi.org/10.1080/02513625.2012.721611

Ekho Moskvi. (2008, April 1). The number of illegal migrants in Moscow may reach 3 million. Retrieved from http://echo.msk.ru/news/504975-echo.html

Federal State Statistics Service. (2010). Rosstat. Russian Census 2010. Population structure by municipalities. Retrieved January 10, 2015, from http://www.gks.ru/free_doc/new_site/perepis2010/croc/perepis_itogi1612.htm

Federal State Statistics Service. (2012). Rosstat. Statistical database. Municipal Database. Retrieved January 10, 2015, from http://www.gks.ru/free_doc/new_site/bd_munst/munst.htm

Federal State Statistics Service. (2013). Rosstat. Statistical database. Regions of Russia. Socio-economic indicators. Retrieved from http://www.gks.ru/bgd/regl/B13 14p/Main.htm

Fischer-Tahir, A., \& Naumann, M. (2013). Introduction: Peripheralization as the social production of spatial dependencies and injustice. In Peripheralization (pp. 9-26). Springer. Retrieved from http://link.springer.com/chapter/10.1007/978-3-531-19018-1_1 
Frome, E. L. (1983). The analysis of rates using Poisson regression models. Biometrics, 665-674.

Garnier, S. (2016). viridis: Default Color Maps from "matplotlib" (Version 0.3.3). Retrieved from https://CRAN.Rproject.org/package $=$ viridis

Gdaniec, C. (2005). Kommunalka und Penthouse: Stadt und Stadtgesellschaft im postsowjetischen Moskau. LIT Verlag Münster.

Gentile, M. (2015). The Post-Soviet Urban Poor and Where They Live: Khrushchev-Era Blocks,"Bad" Areas, and the Vertical Dimension in Luhansk, Ukraine. Annals of the Association of American Geographers, (ahead-of-print), $1-21$.

Gentile, M., \& Sjöberg, Ö. (2006). Intra-urban landscapes of priority: the Soviet legacy. Europe-Asia Studies, 58(5), 701-729. http://doi.org/10.1080/09668130600731268

Haase, A., Grossmann, K., \& Steinführer, A. (2012). Transitory urbanites: New actors of residential change in Polish and Czech inner cities. Cities, 29(5), 318-326. http://doi.org/10.1016/j.cities.2011.11.006

Hausladen, G. (1985). Containing the growth of Moscow: Comparisons with London. Cities, 2(1), 55-69. http://doi.org/10.1016/0264-2751(85)90062-9

Hess, D. B., Tammaru, T., \& Leetmaa, K. (2012). Ethnic differences in housing in post-Soviet Tartu, Estonia. Cities, 29(5), 327-333. http://doi.org/10.1016/j.cities.2011.10.005

Kährik, A., Leetmaa, K., \& Tammaru, T. (2012). Residential decision-making and satisfaction among new suburbanites in the Tallinn urban region, Estonia. Cities, 29(1), 49-58. http://doi.org/10.1016/j.cities.2011.07.005

Kährik, A., Temelová, J., Kadarik, K., \& Kubeš, J. (2016). What attracts people to inner city areas? The cases of two post-socialist cities in Estonia and the Czech Republic. Urban Studies, 53(2), $355-372$. http://doi.org/10.1177/0042098014567444

Karsten, L. (2007). Housing as a Way of Life: Towards an Understanding of Middle-Class Families' Preference for an Urban Residential Location. Housing Studies, 22(1), 83-98. http://doi.org/10.1080/02673030601024630

Kashnitsky, I. S., \& Mkrtchyan, N. V. (2014). Russian periphery is dying in movement: a cohort assessment of Russian internal youth migration based on Census data. NIDI Working Papers, 2014/14. Retrieved from www.nidi.nl/shared/content/output/papers/nidi-wp-2014-14.pdf

Kashnitsky, I. S., Mkrtchyan, N. V., \& Leshukov, O. V. (2016). Interregional migration of youths in Russia: a comprehensive analysis of demographic statistics. Educational Studies Moscow, 13(3), 169-203. http://doi.org/ 10.17323/1814-9545-2016-3-169-203

Kirillov, P. L., \& Makhrova, A. G. (2012). Multiscale analysis of demographic situation transition in Moscow in the post-soviet period. SPERO, 17, 35-56.

Kubeš, J. (2013). European post-socialist cities and their near hinterland in intra-urban geography literature. Bulletin of Geography. Socio-Economic Series, 19(19), 19-43.

Lee, E. S. (1966). A theory of migration. Demography, 3(1), 47-57.

Makhrova, A. G. (2006). Rinok zhiliya i rasselenie v Moskovskom regione (Housing market and settlement in the Moscow region). Demoscope Weekly, 247-248. Retrieved from http://demoscope.ru/weekly/2006/0247/tema01.php

Makhrova, A. G., \& Golubchikov, O. Y. (2012). Rossiiskiy gorod v usloviyakh kapitalizma: sotsialnaya transformatsiya vnutrigorodskogo prostranstva (A Russian city under capitalism). Vestnik MSU. Geography, (2), $26-31$.

Makhrova, A. G., Nefedova, T. G., \& Treivish, A. I. (2013). Moscow agglomeration and "New Moscow": The capital city-region case of Russia's urbanization. Regional Research of Russia, 3(2), 131-141. http://doi.org/10.1134/S2079970513020081

Makhrova, A. G., \& Nozdrina, N. N. (2002). Differentsiatsia na rinke jilya v Moskve kak proyavlenie sotsialnogo rassloeniya naseleniya (Housing market differentiation in Moscow as the feature of social inequality). Vestnik MSU. Geography, (3), 44-50.

Marcińczak, S. (2012). The evolution of spatial patterns of residential segregation in Central European Cities: The Łódź Functional Urban Region from mature socialism to mature post-socialism. Cities, 29(5), 300-309. http://doi.org/10.1016/j.cities.2011.08.008

Marcińczak, S., Gentile, M., Rufat, S., \& Chelcea, L. (2014). Urban Geographies of Hesitant Transition: Tracing Socioeconomic Segregation in Post-Ceauşescu Bucharest. International Journal of Urban and Regional Research, 38(4), 1399-1417. http://doi.org/10.1111/1468-2427.12073 
Marcińczak, S., Gentile, M., \& Stępniak, M. (2013). Paradoxes of (post) socialist segregation: Metropolitan sociospatial divisions under socialism and after in Poland. Urban Geography, 34(3), 327-352.

Marcińczak, S., Musterd, S., \& Stępniak, M. (2012). Where the grass is greener: social segregation in three major Polish cities at the beginning of the 21st century. European Urban and Regional Studies, 19(4), 383-403.

Mulder, C. H., \& Wagner, M. (1998). First-time Home-ownership in the Family Life Course: A West German-Dutch Comparison. Urban Studies, 35(4), 687-713. http://doi.org/10.1080/0042098984709

Mulder, C. H. (2006). Population and housing: A two sided relationship. Demographic Research, 15, 401-412. http://doi.org/10.4054/DemRes.2006.15.13

Musterd, S. (2005). Housing Mix, Social Mix, and Social Opportunities. Urban Affairs Review, 40(6), 761-790. http://doi.org/10.1177/1078087405276006

Musterd, S., Marcińczak, S., Van Ham, M., \& Tammaru, T. (2015). Socio-Economic Segregation in European Capital Cities: Increasing Separation between Poor and Rich. Retrieved from http://papers.ssrn.com/sol3/papers.cfm?abstract_id=2713024

Musterd, S., \& Van Kempen, R. (2009). Segregation and housing of minority ethnic groups in Western European cities. Tijdschrift Voor Economische En Sociale Geografie, 100(4), 559-566.

Plantinga, A. J., Détang-Dessendre, C., Hunt, G. L., \& Piguet, V. (2013). Housing prices and inter-urban migration. Regional Science and Urban Economics, 43(2), 296-306. http://doi.org/10.1016/j.regsciurbeco.2012.07.009

Popov, A. A. (2014). Prostranstvenno-vremennoj analiz faktorov tsenoobrazovaniya na rinke zhiloj nedvizhimosti (Spatiotemporal analysis of key factors for residential real estate estimates in Moscow). Regionalnie issledavaniya (Regional Research), 46(4), 70-80.

Quillian, L. (2002). Why is Black-White Residential Segregation So Persistent? Evidence on Three Theories from Migration Data. Social Science Research, 31(197-229).

Ravenstein, E. G. (1885). The Laws of Migration. Journal of the Statistical Society of London, $2,167$. http://doi.org/10.2307/2979181

RBC. (2013). Real estate. Monthly ratings. Retrieved March 15, 2015, from http://rating.rbc.ru/category.shtml?realty

R Core Team. (2016). R: A Language and Environment for Statistical Computing (Version 3.2.4). Vienna, Austria: R Foundation for Statistical Computing. Retrieved from https:/www.R-project.org/

Round, J., \& Williams, C. (2010). Coping with the social costs of transition: Everyday life in post-Soviet Russia and Ukraine. European Urban and Regional Studies, 17(2), 183-196.

Rudolph, R., \& Brade, I. (2005). Moscow: Processes of restructuring in the post-Soviet metropolitan periphery. Cities, 22(2), 135-150. http://doi.org/10.1016/j.cities.2005.01.005

Schelling, T. C. (1972). A process of residential segregation: Neighborhood tipping. In Pascal A. (Ed.), Racial Discrimination in Economic Life (pp. 157-184). Lexington and MA: D.C. Health.

Shmatko, J. O. (2014). Analiz i otsenka neregistriruemoy migratsii v Rossii (Analysis and estimation of undocumented migration in Russia). Demoscope Weekly, (605-606). Retrieved from http://demoscope.ru/weekly/2014/0605/student01.php

Smith, A., \& Timár, J. (2010). Uneven transformations: Space, economy and society 20 years after the collapse of state socialism. European Urban and Regional Studies, 17(2), 115-125.

Smith, D. M. (1996). The socialist city. In Cities after Socialism: Urban and Regional Change and Conflict in Postsocialist Societies (pp. 70-99). Oxford: Blackwell. Retrieved from http://onlinelibrary.wiley.com/doi/10.1002/9780470712733.ch3/summary

Sørensen, J. F. L. (2014). The impact of residential environment reputation on residential environment choices. Journal of Housing and the Built Environment, 30(3), 403-425. http://doi.org/10.1007/s10901-014-9419-0

Sýkora, L. (1999). Processes of Socio-spatial Differentiation in Post-communist Prague. Housing Studies, 14(5), 679701. http://doi.org/10.1080/02673039982678

Sýkora, L. (2009). New Socio-Spatial Formations: Places of Residential Segregation and Separation in Czechia. Tijdschrift Voor Economische En Sociale Geografie, 100(4), 417-435. http://doi.org/10.1111/j.14679663.2009.00550.x

Szelenyi, I. (1978). Social Inequalities in State Socialist Redustributive Economies. Internation Journal of Comparative Sociology, 19(1-2), 63-87. 
Szelenyi, I. (1987). Housing Inequalities and Occupational Segregation in State Socialist Cities. International Journal of Urban and Regional Research, 11, 1-8.

Theil, H. (1979). The measurement of inequality by components of income. Economics Letters, 2(2), $197-199$.

Trubina, E. G. (2011). Gorod v teorii: opiti osmisleniya prostranstva (The theory of a city). Moscow: Novoe literaturnoe obozrenie.

Tyuryukanova, E. V. (2009). Trudovie migranti v Moskve: "vtoroe" obshestvo (The labor migranys in Moscow: an "alternative" society). In Immigranti $v$ Moskve. Tri kvadrata. Retrieved from http://www.demoscope.ru/weekly/2009/0389/analit01.php

Vakulenko, E. S., \& Tsimaylo, V. V. (2011). Uchet nelegal'noy migratsii naseleniya: metody i otsenki (Estimating illegal migration). Demoscope Weekly, (479-480). Retrieved from http://www.demoscope.ru/weekly/2011/0479/analit02.php

Van Ham, M., \& Manley, D. (2009). Social housing allocation, choice and neighbourhood ethnic mix in England. Journal of Housing and the Built Environment, 24(4), 407-422. http://doi.org/10.1007/s10901-009-9158-9

Van Ham, M., \& Tammaru, T. (2016). New perspectives on ethnic segregation over time and space. A domains approach. Urban Geography, 1-10. http://doi.org/10.1080/02723638.2016.1142152

Vendina, O. I. (1997). Transformation processes in Moscow and intra-urban stratification of population. GeoJournal, 42(4), 349-363. http://doi.org/10.1023/A:1006890108182

Vendina, O. I. (2002). Social Polarization and Ethnic Segregation in Moscow. Eurasian Geography and Economics, $43(3), 216-243$.

Vendina, O. I. (2009). Chastnoe i obshestvennoe v gorodskom prostranstve: ot teorii k moskvskim realyam (The personal and the public in the urban space). Izvestiya RAN. Geography, (2), 28-38.

Vendina, O. I. (2012). Migranti v rossijskikh gorodakh (Migrants in Russian cities). Otechestvennie zapiski, 177-178(3). Retrieved from http://www.strana-oz.ru/2012/3/migranty-v-rossiyskih-gorodah

Vendina, O. I. (2013). Dve Moskvi: mirovozzrenie moskvichey i differentsiatsia gorodskogo prostranstva (Two Moscows). Wemoscope Weekly, (557-558). Retrieved from http://www.demoscope.ru/weekly/2013/0557/analit04.php

Weck, S., \& Beißwenger, S. (2014). Coping with Peripheralization: Governance Response in Two German Small Cities. European Planning Studies, 22(10), 2156-2171. http://doi.org/10.1080/09654313.2013.819839

Weclawowicz, G. (2002). From Egalitarian Cities in Theory to Non-egalitarian Cities in Practice: the Changing Social and Spatial Patterns in Polish Cities. In P. Van Marcuse \& R. Van Kempen (Eds.), Of states and cities (pp. 183 199).

Welch, B. L. (1951). On the comparison of several mean values: an alternative approach. Biometrika, 330-336.

White, P. (1998). The Settlement Patterns of Developed World Migrants in London. Urban Studies, 35(10), 1725-1744. http://doi.org/10.1080/0042098984123

Wickham, H. (2016a). ggplot2: An Implementation of the Grammar of Graphics (Version 2.1.0). Retrieved from https://cran.r-project.org/package=ggplot $2 /$

Wickham, H. (2016b). tidyr: Easily Tidy Data with `spread()’ and 'gather() ' Functions (Version 0.4.1). Retrieved from https://CRAN.R-project.org/package=tidyr

Wickham, H., \& Francois, R. (2015). dplyr: A Grammar of Data Manipulation (Version 0.4.3). Retrieved from https://CRAN.R-project.org/package=dplyr

Wilke, C. O. (2016). cowplot: Streamlined Plot Theme and Plot Annotations for "ggplot2" (Version 0.6.1). Retrieved from https://CRAN.R-project.org/package=cowplot

Yashunsky, A. D., \& Zamyatina, N. Y. (2012). Mejregionalnie tsentri obrazovaniya (Inter-regional centers of education). Otechestvennie zapiski, (3). Retrieved from http://www.strana-oz.ru/2012/3/mezhregionalnye-centryobrazovaniya

Zayonchkovskaya, Z. A., \& Mkrtchyan, N. V. (2009). Rol' migratsii v dinamike chislennisti i sostava naselenija Moskvi (The role of migration in the dynamics of Moscow population size and structure). In Immigranti v Moskve (pp. 18-44). Tri kvadrata. Retrieved from http://publications.hse.ru/chapters/83121502

Zubarevich, N. V. (2012). Moskva na fone drugikh krupneyshikh gorodov Rossii: chto pokazyvaet statistika (Moscow against a background of other biggest Russian cities). SPERO, 17, 57-68. 